\title{
Value Chain Governance Construction under Silk Road Economic Belt
}

\section{development pattern}

\author{
Li Jing \\ Department of economic management, Xi'an University of Arts and Science, China \\ 346591653@163.com
}

Keywords: Silk Road economic belt; Industrial division; Value chain; Governance

\begin{abstract}
As connecting Asia, Europe and the economic strategy a major thoroughfare, the Silk Road economic belt exhibit low ends of the economic development pattern of high intermediate, Europe, the higher level of economic development in East Asia, Central Asia, the Middle East, slower economic growth, industrial reasonable division of labor, but the development of highly complementary; article based on the pattern of economic development with the Silk Road, from different countries, endowments, distribution of benefits and the perspective of industrial upgrading resources value chain analysis of the Silk Road, the four control modes: attachment type, grade system, module type, relationship type. Silk proposal of building a suitable value chain governance model to promote win-win development strategy along the country's economy.
\end{abstract}

\section{Introduction}

In $1877 \mathrm{Mr}$ Leahy also formally put forward the concept of "silk road", "silk road" is defined as connecting Asia, Europe, the three continents strategic channel[1]. On the 21st century, with the progress of modern transportation and communication technology, objectively shortened when the distance of the space, reduce the cost of the national foreign trade along the silk road has close economic ties between countries.

\section{The silk road economic belt economy development pattern}

Economic development trend of high middle and low on both ends. Depending on the level of economic development, the silk road economic belt can be divided into eastern, central and western three plates[2]. The eastern connects the rapid development of the asia-pacific economic circle, the central part of the five central Asian countries economic development is relatively slow, forming a hollow zone, the western European economic circle, the more developed the economy connects the features three plate level of economic development trend of high middle and low on both ends.

Represented by China Eastern plate, rely on the deepening of reform and opening up in the field of economic system and industrial upgrading, and maintaining rapid economic growth, mid towards industrialization; Central plate is rich in natural resources, but most of the resources in less developed countries, the five central Asian countries, for example, at present most of the economic trade development relying on resources, in the underdeveloped stage. Only in the Middle East is one of the few resources of petroleum exporting countries high-income countries[3]; The western sector including economic developed countries, such as the European Union, with capital and technology driven as the main mode of economic growth, has entered the post-industrial era. 
Industry division of labor between different countries are highly complementary to each other. Although different countries with different economic development levels of the silk road economic belt, but features three complementary plate industry development is stronger, division of broad cooperation space. Abundant labor resources, eastern plate manufacturing industry developed, known as the remarkable global processing plants, clothing, toys, electronic products, such as wood processed products continuously from here to the world, but in addition to a few countries such as Japan has the high-end technology, complete industrial system, most east Asian countries are mainly external processing or OEM production, in the industrial chain and mid-range. Plate in eastern as a big country, China's basic industries with excess capacity, need vast overseas investment and product markets; Central plate energy, enrichment of mineral resources, the Middle East area mainly rely on oil output to develop the economy, giving full play to the advantages of energy is its cooperation with other countries in the development of key areas, still need to strengthen and silk road between countries in the field of agricultural cooperation, make up for the disadvantages of ecological environment. Single central Asian country industry system, science and technology backward, underdeveloped productivity, in the traditional industry manufacturing low-end, need to take advantage of resources, improve the ability of international capital and technology investment attracting. Is located in the silk road of western European countries more developed industry, relying on its advanced technology and gather capital, controlled product research and development, brand marketing, such as the industrial chain of high-end, but mainly the lack of natural resources, to maintain the industry high value-added income under the background of globalization, must expand the development space.

Adam Smith pointed out that division of labor is the source of economic growth[4]. The division of production caused by globalization, making the product value creation system component of scattered in different countries or regions, the silk road in the three countries play their respective comparative advantage of factor endowments of the plates, through participation in international division of labor, strengthen economic cooperation, the national industrial system, promote the adjustment of industrial structure, promote economic development speed and quality.

\section{Embedded in the silk road economic belt along the value chain is the country's inevitable choice}

The concept of the value chain from the areas of management. For the analysis of enterprise competitive advantage in the $1980 \mathrm{~s}$, potter systematically investigates the production process each link between contact each other and mutual restriction relationship, on the basis of this the first time put forward the concept of value chain: based on the different division of labor and create link the value of a product, ultimately form a complete series of production activities[5].

Fragments of division of labor in production process. Al ents, points out that the production process of fragmented, make each value of the same value chain link space transfer into international production networks. Based on the purpose of economic development of countries along the silk road, must choose to play its comparative advantage, actively participate in international division of labor and cooperation of production, embedded in the silk road economic belt value chain.

The embedded value chain by different resources endowment. Countries along the silk road resources differences in factor endowments, its economic development level fall of on any account is larger, the industrial structure is different, but are highly complementary to each other. In the international production networks, given the lower the price of factors of production, the lower the cost of the product, product value in the process of the formation of the greater the demand for 
factors of production, for the factors of production value link space restructuring for the more urgent[6]. Therefore, a lower cost of production factors form the value chain to improve the efficiency of resource allocation of value chain. Silk road economic belt in eastern countries rich labor resources, labor force factors of production, low prices for the manufacture of the embedded value chain link; Central country is rich in natural resources, as energy exporting countries, usually embedded transnational production of raw materials to provide link; Western countries abundant capital and advanced technology, to embed the research and development, marketing link of the value chain.

By comparative advantage changes embedded value chain. After the second world war, with the silk road in the western sector eu countries economic growth and continuous improvement of national income, the enterprise gradually lost in the comparative advantage of labor-intensive products production value link, in order to maintain its capital intensive, the core technology and strategic value of comparative advantages, the developed countries will many without its comparative advantage in the industry value chain link of the value of the transfer to developing countries, to spin out the fragments of non-core parts production out and turned to global sourcing, to reduce cost and improve profit margins; At the same time, through the way such as outsourcing production and foreign investment, to a large number of labor-intensive products shift production to developing countries, developing countries enterprise has obtained the good opportunity of inserting into global value chain, objectively promoted the development along the silk road after national capital accumulation and technology progress, promoted the value link spatial restructuring. With the comparative advantage of labor-intensive enterprises in developing countries, and more choose to embed the low value added value link of value chain as a starting point to develop the economy. By embedding in global value chain the value of the labor-intensive links, like Japan and the "Asian tigers" successively took to the road to success for late-development country economic development has a strong demonstration effect.

Because of institutional change factors embedded value chain. Developed countries and developing countries need each other, in the process of transnational production agreed through consultation: gradually reduce and eliminate tariffs and other barriers to trade, establish free trade area, lower transaction costs, improve production efficiency, promote the formation of the international industrial chain and value chain. Many elimination of trade barriers and promote the integration of production aspects of reform measures, to reduce the cost of transnational production space restructuring provides the system guarantee, encourage enterprises to actively embedded industry value chain.

Transnational production, constitute the product value of each link different factor endowments and comparative advantage to the dispersed in different countries and regions, each other in a series of cater to industrial policy support, the silk road countries enterprise respectively the different value of inserting into global value chain link. In the silk road in the western sector of the European Union countries encourage labor-intensive non-core industry to transfer abroad, eastern central plate developing countries are implementing economic opening to the outside world policy, actively participate in international division of labor, prompted multinational production closer cooperation. By the various countries' economic system reform, economic development factors of production in the process of dynamic change of comparative advantage, improve the core competitiveness of embedded in different links of value chain, promoting regional economic growth. Dominated by economic policy communication, road unicom, on the basis of the "three links" good currency circulation, the process of the embedded value chain of countries along the silk road. 


\section{The silk road economic belt construction of value chain governance mode}

Play resources endowment comparative advantages, and actively participate in international division of labor, embedded the global value chain, can promote the economic growth of countries along the silk road economic belt. Embedded value chain, however, does not mean to get equal value.

In the product value creation, how to organize and coordinate different countries to participate in the international division of labor and embedded value chain of each link, build appropriate mode of value chain management, is a common concern of the countries along the silk road.

Types of value chain governance. Humphrey and schmitz: value chain management, is refers to the various economic entities in the value chain activity between different value creation link to take a series of non-market coordination.

Value chain management mode can be divided into: peers, hierarchy and module type, four relational governance mode.

Peers governance mode: many small and medium sized components supporting enterprises, attachment around a core components manufacturing enterprises. Has dominated the value chain, core parts manufacturing enterprises to provide supporting production of parts and components manufacturing enterprises with strong control ability.

Hierarchical governance pattern: the enterprise for the strategic value chain link, and adopts the top-down control means to coordinate the relationship between the enterprise in the process of value creation.

Module type management mode: that make up the value chain of the value chain into design, development, manufacturing, brand building, marketing channels, such as module, in the form of technical specifications to establish standardized module, integration of standardized module to complete the product value creation. Type of module is between the enterprise value chain governance mode of cooperative relations.

Relational governance mode: embedded between different value chain of enterprise value chain, complementary to each other is a kind of ability, technology exchange, market share collaboration, complementary relationship.

Build suitable for silk road economic belt value chain governance strategy. Because of their resources endowment comparative advantage and industrial structure, enterprise of countries along the silk road embedded in different links of value chain. The added value of the value chain of each link of value is different, the overall rendering of high middle and low on both ends of the "smiling curve". Control research and development, design and brand management in the developed countries such as high-end value chain, usually occupy the ends of the "smiling curve", economic backwardness is at the bottom of the squeezed state.

In the construction of a value chain management mode, the conflict when they participate in division of labor cooperation and benefit distribution, performance for industrial upgrading and the upgrade, industry monopoly and anti-monopoly of demarcation.

The developed countries on the silk road economic belt value chain governance mode choice

Plate silk road economic belt in western developed countries, in order to maintain its monopoly profits, from strategy will have of developing countries inserting into global value chain enterprises firmly locked in low value-added links, and attached to the developed countries for a long time. Focusing on the hierarchy of peers or choice of the mode of value chain management, at the expense of developing countries at the expense of economic growth in developed countries monopoly profits. 
Enterprises in the developed countries to consolidate its strategic value in the global value chain link status, usually to link such as low value-added labor-intensive value after restructuring to developing countries, on the one hand, through the way of sustained demand, compression in the mid-range value chain of enterprise profit space in developing countries. On the other hand use frequent upgrading products and strict way of safety, environmental barriers to access, forcing out continuously developing countries enterprise existing production equipment, to the strategic value chain of the enterprises in developed countries the introduction of advanced production equipment, more enterprises in developing countries have to for a long time in low value-added value chain.

In fact, the silk road economic belt "around the resources endowment are highly complementary to each other and have different comparative advantages, regional cooperation and win-win space is large enough. Build suitable for silk road economic belt of the value chain governance mode, should break the monopoly of multinational companies in the developed countries on the global value chain, to promote the benign cooperation of countries along the way and economic sustainable development.

Developing countries build silk road economic belt value chain governance strategy. Developing countries tend to choose module type or relational value chain governance patterns of these two kinds of collaboration, to prevent links at a disadvantage in the profit distribution, etc. Only through the following industrial upgrading strategy of embedded in the high-end link of value chain, to build equal cooperation model of value chain governance.

First, developing countries should take the initiative to participate in international economic division of Labour. To developing countries for their sustained economic growth is usually embedded to conform to the mid-range value link as a starting point of the comparative advantages of economic development. With economic growth, however, resources gradually changes of factor endowments, weakened labor comparative advantage, in order to "low-cost competition model" low-end value embedded value chain link of economic growth space is smaller and smaller, environment, energy become the bottleneck of restricting economic development. Fortunately, in the process of participation in international production, developing countries to improve the enterprise production technology, create the necessary condition for industrial upgrading.

Second, the introduction of imitation, independent innovation is an important way of promoting the product upgrade

First of all, through the introduction of foreign advanced technology, production equipment, can effectively reduce the product research and development in developing countries the cost of trial and error, developing countries enterprises to grasp the new technology as soon as possible, as far as possible, shorten the massive investment in fixed assets to update time, help to improve the efficiency of products and technological process for upgrading.

Then, through independent innovation, promote domestic industrial upgrading. Enterprises in the market, product and technology, management and marketing model of continuous innovation, improve the core technology research and development ability, implementation process, product and function upgrade. To establish its own intellectual property rights and patent strategy, promote enterprise's core competitiveness in developing countries.

Third, from the domestic market, occupy the high-end value chain, upgrades and chains to realize product functions

Developing countries to achieve industrial upgrading, to occupy the strategic value link, will prevent the upgrading of enterprises in developed countries set the trap, prevent is locked into the global value chain of low value-added value chain. And restrictions in order to deal with foreign industrial upgrading block, the suggestion of developing countries start from oneself, using the 
rapid growth of the domestic market, occupying a specific region of domestic strategic value link in higher value-added products value chain, and gradually expand the scope of strategic value link of value chain, gradually penetrate into the surrounding countries with similar needs, finally into the developed markets, establish a modular, or relational governance mode of global value chain. Starting from the domestic market, to establish their own brands and marketing channel, occupy the high-end value chain, is a developing country enterprise realize the product function and the feasibility of the path chain upgrade. Companies in developing countries only use protect their own industry economic policy conditions, possible within the scope of its first part based on the development of high value-added products value chain strategy, and then try to extend into the global value chain. In the process of strategic value link extends outward, talents and multinational companies to compete industry fair in developed countries, achieve the function of the global value chain upgrade and chain upgrade.

Begins by processing production, participate in international division of labor into Japan in the global value chain, the late embedded high value-added strategic value chain, achieving industrial upgrading, the reason of its success has two, one is internal: used to protect domestic market economic policy, swiftly realize industry upgrading. The second is external, by setting the higher taxes and other trade barriers, restricting foreign products into the domestic market, maintain the market competitiveness of domestic enterprises, promote industrial upgrading.

\section{Conclusion}

Construction of Silk Road Economic Belt value chain governance, is the ultimate embodiment of balancing the interests of all countries and the dynamic loss results of economic integration and spatial reorganization of the value chain. By the factor endowment, from low value-added sectors into multinational value chain, is the only way which must be passed after the nation's economic development.

The silk road construction mode of governance best value chain, is conducive to promote the healthy development of Silk Road Economic Belt, is conducive to the stability and sustainable development of the global economy.

\section{Acknowledgement}

This paper was aided by the Special Science Research Planning Project of the Educational Department of Shaanxi Province(No.15JK2141)

\section{References}

[1] Dong suocheng . Silk road economic belt economy development pattern and mode of regional economic integration resources science, 2014, 4 (1)

[2]The Chinese news. Xi delivered an important speech calling for building economic belt "silk road" [EB/OL].

http://www.chinanews.com/gn/2013/09- 07/5257748. SHTML, 2013-09-07/2013-09-07.

[3] Hu angang. "the silk road economic belt" : connotation, strategic positioning and implementation path [J]. Journal of xinjiang normal university (philosophy and social sciences edition), 2014, 35 (2) : 1-10. 
[4] Guo ai-jun , Mao Jinhuang. Silk road economic belt: advantage industrial spatial differences and industrial spatial layout strategy research [J]. Journal of lanzhou university (social science edition), and 2014 (1) : 40 to 49.

[5] Wang Lan a path to China's manufacturing industry into the global value chain research

[6] sun zhuangzhi. "the silk road economic belt" : a new regional cooperation mode [J]. Journal of xinjiang normal university (philosophy and social sciences edition), 2014, 35 (3) : 36-41. 